\title{
HEWAN SEBAGAI MODEL PENYAKIT INFEKSI PERNAFASAN YANG DISEBABKAN OLEH BAKTERI
}

\author{
Noor Andryan Ilsan ${ }^{1 *}$, Siti Nurfajriah ${ }^{2}$, Maulin Inggraini ${ }^{3}$ \\ 1. Program Studi DIII Teknik Laboratorium Medis, STIKes Mitra Keluarga, Bekasi-Indonesia \\ 2. Program Studi DIII Teknik Laboratorium Medis, STIKes Mitra Keluarga, Bekasi-Indonesia \\ 3. Program Studi DIII Teknik Laboratorium Medis, STIKes Mitra Keluarga, Bekasi-Indonesia
}

Korespondensi: Noor Andryan Ilsan | STIKes Mitra Keluarga |noor.andryan@stikesmitrakeluarga.ac.id

\begin{abstract}
Abstrak
Pendahuluan: Penyakit infeksi pernafasan karena bakteri merupakan penyakit yang memiliki kasus tinggi di Indonesia. Penyakit pernafasan karena infeksi bakteri juga bersifat nosokomial dan dapat menyebar di komunitas. Bakteri yang menyebabkan infeksi pernafasan ini sangat beragam baik dari jenis bakterinya, tingkat resistensinya, maupun tingkat virulensinya. Tingkat virulensi bakteri mempengaruhi konsekuensi penyakitnya pada pasien.

Metode: Dalam menentukan virulensi bakteri secara in vivo, beberapa hewan dapat digunakan sebagai model infeksi pernafasan karena bakteri seperti tikus, ikan zebra (Danio rerio), ngengat lilin (Galleria mellonella), nematoda Caenorhabditis elegans.

Hasil: Dari sudut pandang author, jika menilik biaya dan kemudahan sebagai prioritas, ulat G. mellonella memiliki beberapa keunggulan dibandingkan hewan lain seperti biaya produksi murah, tidak membutuhkan perizinan etik, dapat diinkubasi pada suhu $37^{\circ} \mathrm{C}$, juga sudah banyak publikasi yang menggunakan ulat ini dalam uji virulensi bakteri.
\end{abstract}

Kesimpulan: Review artikel ini akan menjelaskan perbandingan kelebihan dan kekurangan hewan model tersebut dalam model in vivo bakteri infeksi pernafasan.

Kata Kunci: Infeksi bakteri, Penyakit pernafasan, Hewan uji, Galleria mellonella, In vivo.

Diterima 23 November, 2021; Accepted 30 Desember, 2021

\section{PENDAHULUAN}

Penyakit infeksi pernafasan merupakan penyakit yang cukup serius di Indonesia. Indonesia, bersama India, Nigeria, Pakistan, dan China terkomposisi setengah dari kasus total 138 juta kasus pnumonia pada anak kecil secara global di 2015 (Oktaria et al., 2021). Pada 2015, Jumlah total kasus pneumonia pada BALITA Indonesia adalah 3,196,000 dengan rerata insiden kasus 300 kasus per 1000 populasi (Oktaria et al., 2021). Bakteri merupakan salah satu agen mikroorganisme penyebab infeksi pernafasan. Tingkat keparahan gejala infeksinya pada pasien dipengaruhi oleh jenis bakteri dan tingkat virulensinya. Salah satu cara untuk menguji virulensi bakteri penyebab infeksi adalah dengan uji in vivo pada hewan uji. Baru-baru ini peneliti memiliki beberapa pilihan model hewan uji yang tepat untuk penyakit infeksi bakteri, khususnya penyakit infeksi bakteri pernapasan. Setiap model hewan uji memiliki keuntungan dan kekurangan mereka sendiri tergantung banyaknya faktor seperti biaya, efektivitas, waktu, etika dan lainnya. Review ini ingin memberikan beberapa penjelasan singkat tentang penggunaan tikus, ikan zebra (Danio rerio), ngengat lilin (Galleria mellonella), nematoda Caenorhabditis elegans sebagai hewan uji penyakit pernafasan karena bakteri. Sebagai informasi, beberapa strain bakteri dapat menyebabkan infeksi pernapasan seperti Klebsiella pneumoniae, Mycobacterium tuberculosis (diwakili oleh M. marinum) dan Waddlia choncrophila juga mereka dapat menginfeksi manusia dan model hewan ini.

\section{METODE}

Pencarian literatur dilakukan dengan mengidentifikasi semua jenis artikel mengenai efek autogenic training terhadap kecemasan. Database yang digunakan adalah google scholar. Hasil pencarian dibatasi tahun 2016 sampai tahun 2021.serta secara manual memilih artikel yang relevan atau sesuai dengan pertanyaan penelitian.

\section{HASIL}

Tikus 


\section{Keuntungan}

1. Mamalia (tikus) menyediakan banyak rute inokulasi (Bakker-Woudenberg 2003) seperti intranasal dan intratracheal. Rute-rute ini tampaknya paling "diperoleh secara alami"

2. Rute intranasal lebih cepat dan lebih mudah dilakukan tanpa prosedur bedah karena intranasal dapat diterapkan sebagai aerosol (inhalasi pasif)

3. Tikus adalah hewan model yang paling banyak digunakan dalam percobaan infeksi karena murah, mudah dirawat, mudah ditangani dan genomnya dapat dimanipulasi (Leung et al. 2013)

\section{Kekurangan}

1. Biasanya dapat diterapkan menggunakan aerosol (intranasal), namun aerosol membawa potensi besar risiko infeksi dengan patogen udara dan dosis aerosol melalui inhalasi menyebabkan hasil sangat bervariasi (Chen et al. 2011)

2. Untuk menghasilkan penyakit paru-paru akut atau kronis perlu teknik bedah. Namun, penggunaan anestesi umumnya memiliki banyak efek samping (Mizgerd dan Skerrett 2008)

3. Dibandingkan dengan manusia, tikus memiliki beberapa perbedaan seperti struktur anatomi, komposisi seluler epitel trakeobronkial, pertahanan fagositik dan sitokin lokal, respons inflamasi atau kekebalan (Irvin dan Bates 2003), ekspresi seluler yang berbeda dan pengikatan ligan untuk Toll yang dipilih seperti receptor (Apt dan Kramnik 2009). Juga tikus memiliki jaringan bronkus terkait limfoid (BALTs) yang berkembang dengan baik.

4. Tikus resisten dengan terlalu banyak patogen manusia, sehingga cukup sulit untuk menginfeksi mereka dengan bakteri (Aziz et al. 2007)

\section{Gejala dan interpretasi}

Bacteria Waddlia choncrophila was infected using intranasal inoculation. For each mouse we can calculate the severity score graded from 1 (ruffled fur) to 5 (death), with grade 4 attributed to moribund animals (i.e. animals with deficient mobility compromising access to food and water). Intermediates grades 2 and 3 are associated to ruffled fur and respectively one or two others characteristics among conjunctivitis, diarrhea or motility troubles. Animals were monitored at least once daily, and whenever a mouse reached a severity score of 1 , all animals were then monitored every 8 hours until the end of the experiments (Pilloux et al. 2016).

Bakteri Waddlia choncrophila terinfeksi ke saluran pernafasan menggunakan inokulasi intranasal. Untuk setiap tikus, kita dapat menghitung skor keparahan yang dinilai dari 1 (bulu berantakan) hingga 5 (kematian), dengan kelas 4 dikaitkan dengan hewan yang hampir mati (yaitu hewan dengan mobilitas yang rendah karena merdampak pada akses makanan dan air). Intermediet kelas 2 dan 3 dikaitkan dengan bulu berantakan dan masing-masing satu atau dua dari karakteristik lain dapat muncul di antaranya konjungtivitis, diare atau masalah motilitas. Hewan dipantau setidaknya sekali sehari, dan setiap kali tikus mencapai skor keparahan 1, semua hewan kemudian dipantau setiap 8 jam sampai akhir percobaan (Pilloux et al. 2016).

\section{Penelitian dan Temuan Terbaru}

Setelah inokulasi intranasal $2 \times 10^{8} \mathrm{CFU} / \mathrm{mL}$ oleh $W$. chondrophila, tikus kehilangan hingga $40 \%$ dari berat badan mereka, dan lumpuh dengan cepat dari infeksi dengan tingkat kematian mencapai 50\% pada hari ke-4 pasca-inokulasi. Imunohistokimia dan histopatologi paru-paru yang terinfeksi mengungkapkan adanya bakteri yang terkait dengan pneumonia yang ditandai dengan peradangan multifokal yang penting. Skor inflamasi yang tinggi di paru-paru dikaitkan dengan adanya sitokin pro-inflamasi di serum dan paruparu pada hari ke-3 pasca-infeksi. Model tikus mendukung peran W. chondrophila sebagai agen infeksi saluran pernapasan. Model tikus terinfeksi W. chondrophila ini dapat membantu memahami patogenesis bakteri strict intraseluler ini (Pilloux et al. 2016).

\section{Ikan zebra (Danio rerio)}

\section{Keuntungan}

1. Embrio yang terinfeksi oleh bakteri terlihat transparan dan sampai 3 minggu larva cukup tembus pandang dan dapat diterapkan selama berhari-hari setelah pembuahan ( \pm 48 jam sampai menetas) (Ali et al. 2011)

2. Embrio hidup yang terinfeksi mungkin untuk mengikuti real time perkembangan menggunakan teknik flouresen (Redd et al. 2006)

\section{Kekurangan}

Ikan dewasa kurang rentan terhadap infeksi bakteri, oleh karena itu jumlah bakteri hidup yang lebih tinggi diperlukan bila dibandingkan dengan infeksi pada tikus. 
3. Memiliki kemungkinan/cakupan yang luas untuk analisis mutan genom dengan skala besar. Peta genom ikan zebra sudah tersedia (Ramachandran et al. 2010) dan cukup teranotasi (annotated) dengan baik. Lebih dari 26.000 gen pengkodean protein telah diurutkan dan teranotasi, menunjukkan konservasi tinggi antara gen terkait bawaan dan adaptasi dengan ortholog masing-masing pada manusia (Rauta et al. 2012).

4. Sebagian besar komponen dan molekul sistem kekebalan mamalia telah diidentifikasi pada ikan zebra atau pada spesies ikan bertulang keras lainnya (Page et al. 2013) termasuk populasi sel-sel yang menyajikan antigen yang sangat mirip dengan sel dendritik mamalia (Lugo-Villarino et al. 2010). Kekebalan bawaan bersifat fungsional, dengan makrofag dan neutrofil yang aktif pada 48 jam pasca pembuahan. Spesies ini memiliki sistem komplemen aktif yang dapat dimulai / diprakarsai dengan cara yang sama seperti pada mamalia (Sunyer et al., 2005). Sistem kekebalan adaptif juga terdiri dari sel T dan sel B walaupun situs utama untuk presentasi antigen dan pematangan sel $\mathrm{T}$ berlokasi di limpa. Maka dari itu, beberapa gelombang hematopoiesis pada ikan zebra terjadi di lokasi anatomi yang berbeda analog dengan hematopoiesis mamalia (Kanther and Rawls 2010).

5. Ikan zebra telah dianggap sebagai metode pengganti untuk percobaan hewan karena mereka menyajikan beberapa karakteristik unggul seperti tingkat kesuburan yang tinggi, ukuran kecil, perawatan yang mudah, perkembangan cepat dan pertimbangan peraturan dan perizinan etik yang kurang ketat karena telah dianggap bahwa embrio ikan pada tahap perkembangan awal tidak merasakan rasa sakit, penderitaan, atau kesusahan (Strähle et al. 2012)

\section{$\underline{\text { Rute infeksi }}$}

Ikan zebra dewasa biasanya terinfeksi oleh injeksi intraperitoneal atau intramuskular, sedangkan rute infeksi yang paling umum digunakan pada embrio adalah injeksi ke vena kaudal pada 28 jam pasca pembuahan (van Leeuwen et al. 2014).

\section{Gejala dan interpretasi}

For instance, if we are going to generate tuberculosis (Mycobacterium marinum) model using Zebrafish, granulomas will appears as a key feature of human TB. These granulomas are preferentially formed in fatty tissue and are most commonly found in the pancreas, adipose tissue, liver, spleen, and gonads. The first granulomas can already be found in the first weeks postinfection (van Leeuwen et al. 2014). Figure below is flourescent image of a zebrafish embryo infected with red flourescent $M$. marinum (Fig. A with red), phagocytes stained with anti-L-Plastin (Fig. B with green), merge of B and C confirming colonization of these cells in early granulomas in zebrafish embryos. Gambar di bawah ini adalah gambar tepung embrio ikan zebra yang terinfeksi tepung merah M. marinum (Gambar A dengan warna merah), fagosit yang diwarnai dengan anti-L-Plastin (Gambar.B dengan hijau), penggabungan B dan $\mathrm{C}$ yang mengkonfirmasikan kolonisasi sel-sel ini pada granuloma awal pada embrio ikan zebra.

Secara singkat, jika kita akan menghasilkan model tuberkulosis (Mycobacterium marinum) menggunakan ikan zebra, granuloma akan muncul sebagai fitur utama TB manusia. Granuloma ini secara istimewa terbentuk dalam jaringan lemak dan paling sering ditemukan di pankreas, jaringan adiposa, hati, limpa, dan gonad. Granuloma pertama sudah dapat ditemukan pada minggu-minggu pertama pascainfeksi (van Leeuwen et al. 2014).

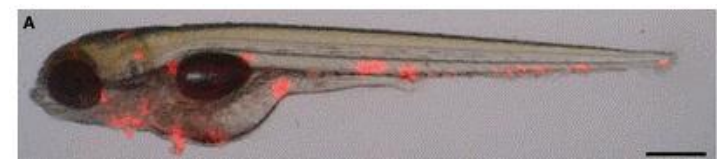

Gambar 1. Perkembangan bakteri M. marinum pada ikan zebra yang terinfeksi kemudian divisualisasikan 
dengan flouresen (van Leeuwen et al. 2014).

Penelitian dan Temuan Terbaru

Penulis membandingkan tiga isolat klinis $K$. pneumoniae kemudian mengevaluasi resistensi mereka terhadap fagositosis, kelangsungan hidup dan kematian intraseluler, kolonisasi usus, dan perekrutan sel kekebalan bawaan menggunakan ikan zebra dan amoeba Dictyostelium discoideum. Hasil mereka menunjukkan bahwa ikan zebra dan $D$. discoideum adalah model inang yang menguntungkan untuk mempelajari berbagai sifat K. pneumoniae yang terkait dengan virulensi (Marcoleta et al. 2018).

\section{Caenorhabditis elegans (Nematoda/Non-vertebrata)}

\begin{tabular}{|c|c|c|}
\hline \multicolumn{2}{|r|}{ Keuntungan } & Kekurangan \\
\hline 1 & $\begin{array}{l}\text { C. elegans memiliki keuntungan luar biasa seperti biaya rendah, } \\
\text { kondisi pertumbuhan sederhana, dan waktu generasi yang singkat } \\
\text { dengan garis keturunan sel yang tidak bervariasi. Ada banyak } \\
\text { metode molekuler dan genetik untuk memanipulasinya (Kurz dan } \\
\text { Ewbank 2000). Genom C. elegans sudah mulai diurutkan pada } \\
\text { akhir tahun } 1998 \text { (Schulenburg dan Ewbank 2007) }\end{array}$ & $\begin{array}{l}\text { Nematoda perlu disinkronkan } \\
\text { sekitar } 1 \text { minggu sebelum infeksi } \\
\text { untuk mengurangi variasi hasil } \\
\text { yang terkait dengan perbedaan } \\
\text { usia. Ada dua metode untuk } \\
\text { menyinkronkan cacing yaitu }\end{array}$ \\
\hline 2 & $\begin{array}{l}\text { Dibandingkan dengan tikus, jelas bahwa perkembangbiakan dan } \\
\text { pemeliharaan C. elegans jauh lebih sederhana dan lebih murah. } \\
\text { Selain itu, peraturan etika praktis tidak ada untuk eksperimen } \\
\text { dengan cacing. Mengenai kultur sel, C. elegans stok yang }\end{array}$ & $\begin{array}{l}\text { persiapan telur melalui } \\
\text { pemutihan (bleaching) dan } \\
\text { bertelur (egg lay) (Sulston dan } \\
\text { Hodgkin 1988) }\end{array}$ \\
\hline & $\begin{array}{l}\text { terkontaminasi mudah diidentifikasi dan dibersihkan lebih mudah } \\
\text { daripada sel mamalia yang terkontaminasi (Hulme and } \\
\text { Whitesides 2011) }\end{array}$ & $\begin{array}{l}2 \text { Selain spesies bakterinya, } \\
\text { mekanisme pembunuhan dalam } \\
\text { banyak kasus tergantung pada }\end{array}$ \\
\hline 3 & $\begin{array}{l}\text { C. elegans berbagi kesamaan dengan sistem kekebalan mamalia, } \\
\text { terutama menandakan kaskade dalam kekebalan bawaan dalam } \\
\text { menanggapi invasi patogen (Alper et al. 2008). Karena nematoda } \\
\text { mengkonsumsi mikroorganisme sebagai sumber makanan } \\
\text { mereka, mungkin ada tekanan seleksi untuk berevolusi dan } \\
\text { mempertahankan mekanisme pertahanan kekebalan tubuh } \\
\text { (Shivers et al. 2010). }\end{array}$ & $\begin{array}{l}\text { cara bakteri disiapkan sebelum } \\
\text { infeksi. Misalnya, tergantung } \\
\text { pada komposisi media agar di } \\
\text { mana bakteri tumbuh, tingkat } \\
\text { pembunuhan C. elegans yang } \\
\text { dimediasi } P \text {. aeruginosa akan } \\
\text { berbeda (Tan et al. 1999). Jika }\end{array}$ \\
\hline 4 & $\begin{array}{l}\text { Dalam usus } C \text {. elegans, in mungkin untuk mengidentifikasi faktor } \\
\text { virulensi patogen spesifik yang berinteraksi dengan permukaan } \\
\text { epitel C. elegans (Green et al. 2009) }\end{array}$ & $\begin{array}{l}\text { strain yang diuji } P \text {. aeruginosa } \\
\text { tumbuh pada media minimal, } \\
\text { pembunuhan akan terjadi dalam }\end{array}$ \\
\hline 5 & $\begin{array}{l}\text { Keuntungan menggunakan nematoda sebagai model hewan } \\
\text { infeksi bakteri terletak pada singkatnya waktu percobaan tanpa } \\
\text { perlu aklimatisasi hewan sebelum infeksi, dan kurva waktu } \\
\text { bunuhnya hanya berlangsung beberapa jam (pembunuhan cepat) } \\
\text { atau dapat juga berhari-hari (pembunuhan lambat) pasca-infeksi } \\
\text { tergantung pada mekanisme pembunuhan }\end{array}$ & $\begin{array}{l}\text { beberapa hari; Sebaliknya, jika } \\
\text { media osmolaritas tinggi } \\
\text { digunakan, pembunuhan akan } \\
\text { terjadi dalam beberapa jam. }\end{array}$ \\
\hline 6 & $\begin{array}{l}\text { Lebih dari } 40 \text { patogen manusia, atau kerabat dekat mereka, } \\
\text { diketahui menyebabkan penyakit di } C \text {. elegans (Sifri et al. 2005). } \\
\text { Proses infeksi } C \text {. elegans memiliki keuntungan yaitu sangat mirip } \\
\text { dengan infeksi kronis, karena inang biasanya terinfeksi dosis } \\
\text { patogen maksimal. }\end{array}$ & \\
\hline
\end{tabular}

Gejala dan interpretasi

Rute infeksi berupa pakan yang mengandung Klebsiella pneumonia pada media agar. C. elegans mampu dikultur pada media padat yang mengandung bakteri. Waktu mematikan 50\% (LT50) sesuai dengan waktu (jam) yang diperlukan untuk membunuh 50\% dari populasi nematoda. Waktu yang dibutuhkan bakteri untuk membunuh cacing dibandingkan dengan durasi hidup yang diamati ketika cacing diberi makan dengan strain E. coli (Lavigne et al. 2013).

Penelitian dan Temuan Terbaru

Virulensi isolat $K$. pneumoniae dievaluasi dalam model Caenorhabditis elegans. Produsen dan transforman Klebsiella pneumoniae carbapenemase (KPC) klinis secara signifikan kurang virulen (LT50: 
5,5 hari) daripada strain referensi $K$. pneumoniae (LT50: 4,3 hari) (p, 0,01). Namun, penyebaran bakteri KPC-2 positif strain $K$. pneumoniae ST258 dan strain referensi yang mengandung plasmid diekstrak dari strain $K$. pneumoniae ST258 memiliki virulensi yang lebih tinggi daripada strain KPC-2 jenis ST lainnya (LT50: 5 hari vs 6 hari, p, 0,01). Peningkatan virulensi yang diamati pada strain tidak dipengaruhi oleh gen $b l a^{\mathrm{KPC}-2}$. Gen $b_{l}{ }^{\mathrm{KPC}-2}$ itu sendiri tidak terkait dengan peningkatan virulensi (Lavigne et al. 2013)

\section{Galleria mellonella (larva serangga)}

\begin{tabular}{|c|c|c|}
\hline & Keuntungan & Kekurangan \\
\hline 1. & $\begin{array}{l}\text { Mirip dengan model non-vertebrata lainnya, keuntungannya adalah } \\
\text { biaya pemeliharaan yang rendah dan tidak butuh perizinan etika. } \\
\text { Ada beberapa alat genetik dan molekuler yang tersedia. Dengan } \\
\text { arti lain, metode ini memiliki titik akhir yang tepat. Rendahnya } \\
\text { biaya pemeliharaan dan perkembangan yang cepat, memungkinkan } \\
\text { penggunaannya dalam jumlah yang tinggi untuk analisis statistik } \\
\text { hasil yang tepat (Sprynski et al. 2014) }\end{array}$ & $\begin{array}{l}\text { 1. Sampai saat ini model } G \text {. } \\
\text { mellonella } \\
\text { keterbatasan } \\
\text { menghasilkan organisme larva } \\
\text { rekombinan genetik dan peta } \\
\text { genomnya tidak sepenuhnya } \\
\text { tersedia. }\end{array}$ \\
\hline 2. & $\begin{array}{l}\text { Most insects have a very rapid life cycle. insect rearing is easy and } \\
\text { relatively cheap (Ramarao et al. 2012). For larva, drugs can be } \\
\text { administered directly injecting the organism or mixing with media } \\
\text { (solid or liquid with } 2 \% \text { yeast paste). For adults, drugs may be } \\
\text { delivered as aerosol, mixed with food, injected or applied directly } \\
\text { to the nerve cord. In the injection method, a needle or a } \\
\text { nanoinjector preloaded with pathogen culture is used to prick the } \\
\text { body cavity (insect hemocoel). }\end{array}$ & \\
\hline & $\begin{array}{l}\text { 2. Sebagian besar serangga memiliki siklus hidup yang sangat } \\
\text { cepat. pemeliharaan serangga mudah dan relatif murah (Ramarao } \\
\text { et al. Untuk larva, senyawa aktif obat obatan dapat diberikan } \\
\text { langsung menyuntikkan organisme atau pencampuran dengan } \\
\text { media (padat atau cair dengan pasta ragi } 2 \% \text { ). Untuk serangga } \\
\text { dewasa, senyawa aktif obat obatan dapat dikirim melalui aerosol, } \\
\text { dicampur dengan makanan, disuntikkan atau diterapkan langsung } \\
\text { ke tali saraf. Dalam metode injeksi, jarum atau nanoinjector dapat } \\
\text { dimasukkan ke dalam kultur patogen kemudian dengan menusuk } \\
\text { rongga tubuh (hemocoel serangga). }\end{array}$ & \\
\hline & $\begin{array}{l}\text { Penggunaan larva Galleria mellonella menghemat biaya, dapat } \\
\text { tersedia secara luas dan hasilnya dapat diperoleh dalam waktu } 2 \\
\text { atau } 3 \text { hari }\end{array}$ & \\
\hline & $\begin{array}{l}\text { Manfaat tambahan menggunakan Galleria untuk studi patogenesis } \\
\text { adalah bahwa infeksi dapat dilakukan pada } 37{ }^{\circ} \mathrm{C} \text { atau lebih tinggi, } \\
\text { karena } G \text {. mellonella mentolerir suhu yang relatif tinggi, tidak } \\
\text { seperti ikan zebra, D. melanogaster dan } C \text {. elegans (maksimum } \\
25-28^{\circ} \mathrm{C} \text {; Glavis-Bloom et al. 2012). Ukuran larva Galleria yang } \\
\text { lebih besar, dibandingkan dengan model invertebrata lainnya, juga } \\
\text { memungkinkannya terinfeksi dengan dosis patogen yang lebih } \\
\text { besar dan lebih terkontrol tanpa secara signifikan membuat } \\
\text { serangga tersebut trauma. }\end{array}$ & \\
\hline
\end{tabular}

\section{$\underline{\text { Rute infeksi untuk bakteri (Klebsiella pneumoniae) }}$}

Bakteri ditumbuhkan dalam $5 \mathrm{ml}$ Lactose Broth medium, dipanen selama fase eksponensial dengan disentrifugasi $2.500 \mathrm{~g}$ selama 20 menit pada suhu $24^{\circ} \mathrm{C}$, dan dicuci sekali dengan $10 \mathrm{mM}$ fosfat-buffered saline (PBS; pH 6,5). Bakteri diencerkan dalam PBS dengan kepadatan optik pada $600 \mathrm{~nm}$ (OD600) 1, yang sesuai dengan sekitar $1 \times 10^{9} \mathrm{CFU} / \mathrm{ml}$. Setelah desinfeksi permukaan menggunakan etanol (70\% [vol/ vol]), larva disuntik dengan $10 \mu \mathrm{l}$ suspensi bakteri, yang mengandung sekitar $1 \times 10^{8} \mathrm{CFU} / \mathrm{ml}$, ke dalam proleg kanan terakhir dengan menggunakan jarum suntik Hamilton dengan jarum 30-gauge. Kontrol disuntikkan oleh PBS (Insua et al. 2013).

\section{Gejala dan interpretasi}


K. pneumoniae adalah strain bakteri penting yang menyebabkan infeksi saluran pernapasan seperti pneumonia. Meskipun G. mellonalle tidak memiliki paru-paru sebagai manusia, kita dapat menghitung virulensi total strain bakteri yang telah disuntikkan. Intrepretation bisa dianalogikan seperti gambar di bawah ini (Gambar 2). Larva G. mellonella 5 dan 10 jam setelah disuntik oleh K. pneumoniae muncul lebih gelap di seluruh tubuh dan kegelapan larva yang dipengaruhi oleh waktu inkubasi setelah disuntikkan, diikuti oleh warna hemolimfa yang ikut berubah (Gambar 2A). Setelah 72 jam terinfeksi sebagian besar dari larva mati, oleh karena itu kita dapat mengukur dosis letal. Aktivitas Fenoloxidase (PO) adalah aktivitas enzim yang bisa kita ukur untuk menghitung virulensi bakteri. Gambar 2B menunjukkan bahwa bakteri yang mengandung gen virulensi menghasilkan aktivitas PO yang tinggi, tetapi tidak untuk bakteri dengan gen virulensi yang di-knockout (Insua et al. 2013).

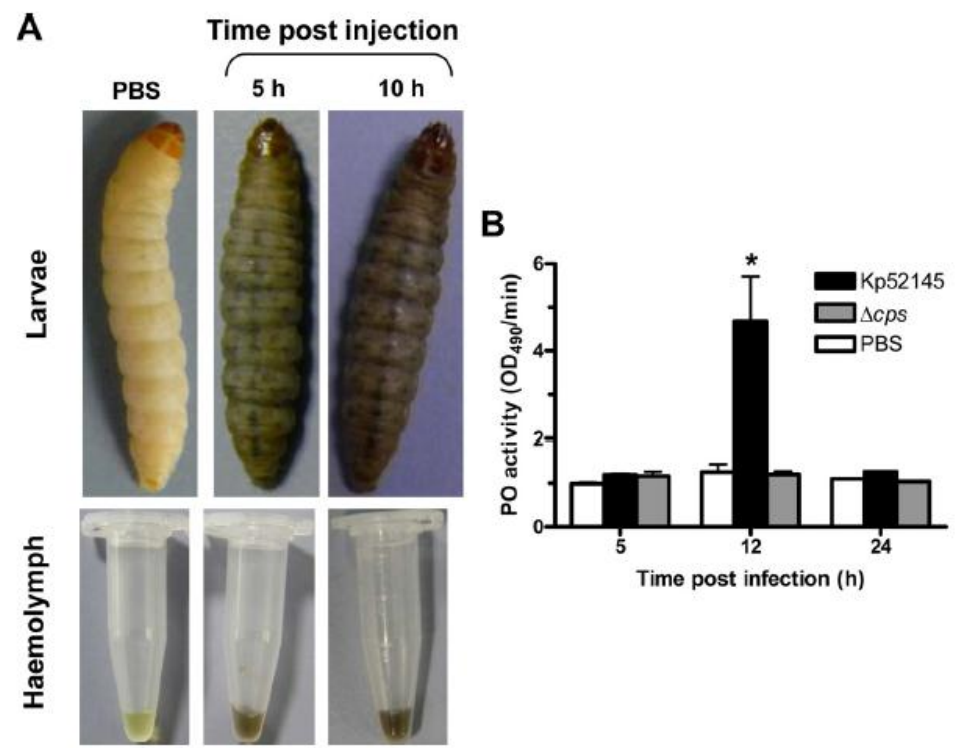

Gambar 2. Interpretasi dan penilaian uji virulensi bakteri yang dilakukan oleh Insua et al, 2013. A.

Penampakan kehitaman pada larva G. mellonella setelah infeksi, dan pengukuran hemolimfa masing masing larva. B. Hasil pengukuran aktivitas PO pada hemolimfa.

\section{Penelitian dan Temuan Terbaru}

Model G. mellonella mampu membedakan antara strain Klebsiella patogen dan non patogen. Penulis menemukan bahwa bakteri mutan yang kekurangan kapsul polisakarida, dekorasi lipid A, atau protein membran luar OmpA dan OmpK36 dakan melemahkan bakteri terhadap larva di G. mellonella. Semua mutan mengaktifkan respons defensif G. mellonella. Model Galleria juga memungkinkan untuk memantau ekspresi gen Klebsiella. Tingkat ekspresi cps dan lokus yang terlibat dalam lipid A akan memuncak selama berjam-jam pertama pasca infeksi, dalam proses yang diregulasi PhoPQ dan Pmr AB. Secara bersama-sama, hasil ini mendukung kegunaan $G$. mellonella sebagai inang pengganti untuk menilai infeksi dengan $K$. pneumoniae (Insua et al. 2013).

\section{PEMBAHASAN}

Model G. mellonella sebagai model respon yang mudah, murah, dan cepat untuk penyakit infeksi bakteri

Dalam beberapa tahun terakhir, tikus menjadi model favorit untuk penyakit infeksi bakteri. Namun, tikus sangat mahal, tidak mudah dipelihara, membutuhkan persetujuan etis, dan periode siklus hidup yang panjang. Baru-baru ini, para peneliti masih mencari untuk memecahkan masalah itu dalam hal model infeksi bakteri. Salah satu model yang menjanjikan adalah larva G. mellonella (ngengat lilin yang lebih besar). Kita dapat menemukan lebih dari seribu artikel telah diterbitkan di PubMed. G. mellonella telah digunakan untuk model infeksi bakteri, infeksi jamur, dan menilai kemanjuran obat antimikroba baik dosis tunggal atau kombinasi.

G. mellonella dapat menjadi model infeksi potensial karena sebagai serangga umum, mereka memiliki 
respons imun bawaan yang berkembang termasuk respons imun seluler dan humoral. Respon seluler dilakukan oleh sel hemosit termasuk prohemosit, plasmasit, sel granular, koagulosit, spherulocytes dan oenocytoids (Browne et al. 2013). Sel-sel ini memiliki fungsi fagositik. Sementara untuk respon humoral diperantarai oleh opsonin seperti apolipophorin (Whitten, Tew, Lee, \& Ratcliffe, 2004), peptidoglycan recognition protein (PGRPs) (Seitz et al., 2003), protein kationik 8 (Kim et al., 2010), dan hemolin (Mowlds et al. 2010). Serangga ini juga memiliki peptida antimikroba termasuk lysozime, cecropin, peptida seperti moricin, gloverin, galiomycin, gallerimycin, defensin, Gm proline-rich (Brown, Howard, Kasprzak, Gordon, \& East, 2009). Infeksi mikroba juga menyebabkan proses melanisasi (penampilan kehitaman) karena respons jalur fenoloksidase (Lu et al., 2014).

Larva G. mellonella dapat diperoleh dari perusahaan, atau dibesarkan di rumah. Ilsan et al. (Ilsan et al. 2021) menggunakan G. mellonella untuk mengevaluasi virulensi Acinetobacter baumannii yang resistan terhadap colistin. Mereka menggunakan larva G. mellonella in-house dengan komposisi adalah dedak gandum (200 gr), bubuk gandum (100 gr), ragi (40 gr), susu bubuk ( 80 gr), gliseri (60 gr), dan madu (200 gr). Larva yang digunakan untuk percobaan mereka adalah larva tahap instar terakhir dengan sekitar 4 minggu dari telur. Mereka menggunakan larva dengan berat 250-350 gr untuk menyamakan ukuran. Larva tumbuh pada $18^{\circ} \mathrm{C}$ di inkubator. Sekitar 24 jam sebelum inokulasi bakteri, larva direkomendasikan untuk kelaparan. Mereka menggunakan 15 larva per kelompok perlakuan dan dilakukan 3 ulangan secara biologis. Setelah inokulasi, larva diinkubasi pada suhu $37^{\circ} \mathrm{C}$ sebagai suhu optimal untuk bakteri yang diinokulasi menjadi larva.

\section{KESIMPULAN}

Beberapa hewan model dapat digunakan untuk infeksi pernafasan karena bakteri yaitu seperti tikus, ikan zebra (Danio rerio), ngengat lilin (Galleria mellonella), nematoda Caenorhabditis elegans. Penting untuk memilih hewan model yang tepat tergantung dari prioritas apa yang diinginkan. Jika prioritasnya adalah biaya dan kemudahan. Larva G. mellonella dapat menjadi opsi dalam model infeksi ini.

\section{UCAPAN TERIMA KASIH}

Alhamdulillah puji syukur kepada Allah swt, karena kehendak dan ridhaNya peneliti dapat menyelesaikan artikel ini. Tidak ada pendanaan khusus terkait pembuatan artikel ini.

\section{REFERENSI}

Ali, S., Champagne, D.L., Spaink, H.P., \& Richardson, M.K. 2011. Zebrafish embryos and larvae: a new generation of disease models and drug screens. Birth Defects Res Embryo Today. 93: 115-133.

Alper, S., Laws, R., Lackford, B., Boyd, W.A., Dunlap, P., \& Freedman, J.H. 2008. Identification of innate immunity genes and pathways using a comparative genomics approach. Proc Natl Acad Sci U.S.A. 105:7016-7021

Apt, A., \& Kramnik, I. 2009. Man and mouse TB: contradictions and solutions. Tuberculosis (Edinb.). 89:195-198

Aziz, R.K., Kansal, R., Abdeltawab, N.F., Rowe, S.L., Su, Y., \& Carrigan D, 2007. Susceptibility to severe Streptococcalsepsis: use of a large setofisogenic mouse lines to study genetic and environmental factors. Genes Immun. 8:404-415

Brannon, M.K., Davis, J.M., Mathias, J.R., Hall, C.J., Emerson, J.C., \& Crosier, P.S. 2009. Pseudomonas aeruginosa Type III secretion system interacts with phagocytes to modulate systemic infection of zebrafish embryos. Cell Microbiol. 11:755-768

Brown, S. E., Howard, A., Kasprzak, A. B., Gordon, K. H., \& East, P. D. 2009. A peptidomics study reveals the impressive antimicrobial peptide arsenal of the wax moth Galleria mellonella. Insect Biochem Mol Biol, 39(11), 792-800. doi:10.1016/j.ibmb.2009.09.004

Browne, N., Heelan, M., \& Kavanagh, K. 2013. An analysis of the structural and functional similarities of insect hemocytes and mammalian phagocytes. Virulence, 4(7), 597-603. doi:10.4161/viru.25906

Chen, B., Weisbrod, T.R., Hsu, T., Sambandamurthy, V., Vieira-Cruz, D., \& Chibbaro, A. 2011. Einstein Contained Aerosol Pulmonizer (ECAP): improved biosafety for multi-drug resistant (MDR) and extensively drug resistant (XDR) Mycobacterium tuberculosis aerosol infection studies. Appl Biosaf. $16: 134-138$ 
Glavis-Bloom, J., Muhammed, M., Mylonakis, E. 2012. Of model hosts and man: using Caenorhabditis elegans, Drosophila melanogaster and Galleria mellonella as model hosts for infectious disease research. Adv Exp Med Biol. 710:11-17

Green, R.M., Gally, F., Keeney, J.G., Alper, S., Gao, B., \& Han, M. 2009. Impact of cigarette smoke exposure on innate immunity: a Caenorhabditis elegans model. PLoSONE. 4(8):e6860

Hulme, S.E., \& Whitesides, G.M. 2011. Chemistry and the worm: Caenorhabditis elegans as platform for integrating chemical and biological research. Angew Chem Int Ed Engl. 50:4774-4807

Ilsan, N. A., Lee, Y. J., Kuo, S. C., Lee, I. H., \& Huang, T. W. 2021. Antimicrobial Resistance Mechanisms and Virulence of Colistin- and Carbapenem-Resistant Acinetobacter baumannii Isolated from a Teaching Hospital in Taiwan. Microorganisms, 9(6). doi:10.3390/microorganisms9061295

Insua, J.L., Llobet, E., Moranta, D., Perez-Gutierrez, C., Tomas, A., Garmendia, J., \& Bengoechea, J.A. 2013. Modeling Klebsiella pneumonia pathogenesis by infection of the wax moth Galleria mellonella. Inf Immun. 81(10):3552-3565

Irvin, C.G., \& Bates, J.H.T. 2003. Measuring the lung function in the mouse: the challenge of size. Respir Res. 4:4

Kanther, M., \& Rawls, J.F. 2010. Host-microbe interactions in the developing zebrafish. Curr Opin Immunol. 22:10-19

Kim, C. H., Shin, Y. P., Noh, M. Y., Jo, Y. H., Han, Y. S., Seong, Y. S., \& Lee, I. H. 2010. An insect multiligand recognition protein functions as an opsonin for the phagocytosis of microorganisms. $J$ Biol Chem, 285(33), 25243-25250. doi:10.1074/jbc.M110.134940

Lavigne, J., Cuzon, G., Combescure, C., Bourg, G., Sotto, A., \& Nordmann, P. 2013. Virulence of Klebsiella pneumoniae isolates harbouring blaKPC-2 carbapenemase gene in a Caenorhabditis elegans model. Plos one. 8(7): 1-7

Leung, C., Chijioke, O., Gujer, C., Chatterjee, B., Antsiferova, O., \& Landtwing, V. 2013. Infectious diseases in humanized mice. Eur J Immunol. 43:2246-2254

Lu, A., Zhang, Q., Zhang, J., Yang, B., Wu, K., Xie, W., . . Ling, E. 2014. Insect prophenoloxidase: the view beyond immunity. Front Physiol, 5, 252. doi:10.3389/fphys.2014.00252

Lugo-Villarino, G., Balla, K.M., Stachura, D.L., Bañuelos, K., Werneck, M.B.F., \& Traver, D. 2010. Identification of dendritic antigen-presenting cells in the zebrafish. Proc Natl Acad Sci U.S.A. 107:15850-15855

Marcoleta, A.E., Varas, M.A., Ortiz-Severin, J., \& Vasquez. 2018. Evaluating different traits of Klebsiella pneumoniae using Dictyostelium discoideum and Zebrafish larvae as host models. Front Cel Infect Microbiol. 8(30):1-20

Mizgerd, J.P., \& Skerrett, S.J. 2008. Animal models of human pneumonia. Am J Physiol Lung Cell Mol Physiol. 294:L387-L398

Mowlds, P., Coates, C., Renwick, J., \& Kavanagh, K. 2010. Dose-dependent cellular and humoral responses in Galleria mellonella larvae following beta-glucan inoculation. Microbes Infect, 12(2), 146153. doi:10.1016/j.micinf.2009.11.004

Oktaria, V., Danchin, M., Triasih, R., Soenarto, Y., Bines, J. E., Ponsonby, A. L., . . Graham, S. M. 2021. The incidence of acute respiratory infection in Indonesian infants and association with vitamin D deficiency. PLoS One, 16(3), e0248722. doi:10.1371/journal.pone.0248722

Page, D.M., Wittamer, V., Bertrand, J.Y., Lewis, K.L., Pratt, D.N., \& Delgado, N. 2013. An evolutionarily conserved program of B-cell development and activation in zebrafish. Blood 122:e1-e11

Pilloux, L., LeRoy, D., Brunei, C., Roger, T., \& Greub, G. 2016. Mouse model of respiratory tract infection induced by Waddlia chondrophila. Plos one. 11(3):1-12

Ramachandran, S., Ruef, B., Pich, C., \& Sprague, J. 2010. Exploring zebrafish genomic, functional and phenotypic data using ZFIN. Curr Protoc Bioinformatics. Chap 1,Unit1.18

Ramarao, N., Nielsen-Leroux, C., \& Lereclus, D. 2012. The Insect Galleria mellonella as a powerful infection model to investigate bacterial pathogenesis. $J$ Vis Exp. 70:e4392

Rauta, P.R., Nayak, B., Das, S. 2012. Immune system and immune responses in fish and their role incomparative immunity study: a model for higher organisms. Immunol Lett. 148:23-33

Redd, M.J., Kelly, G., Dunn, G., Way, M., \& Martin, P. 2006. Imaging macrophage chemotaxis in vivo: studies of microtubule function in zebrafish wound inflammation. Cell Motil Cytoskeleton. 63:415-422 
Ruyra, A., Cano-Sarabia, M., García-Valtanen, P., Yero, D., Gibert, I., \& Mackenzie, S.A. 2014. Targeting and stimulation of the zebrafish (Danio rerio) innate immune system with LPS/dsRNA-loaded nano liposomes. Vaccine 32, 3955-3962

Schulenburg, H., \& Ewbank, J.J. 2007. The genetics of pathogen avoidance in Caenorhabditis elegans. Mol Microbiol. 66:563-570

Seitz, V., Clermont, A., Wedde, M., Hummel, M., Vilcinskas, A., Schlatterer, K., \& Podsiadlowski, L. 2003. Identification of immunorelevant genes from greater wax moth (Galleria mellonella) by a subtractive hybridization approach. Dev Comp Immunol, 27(3), 207-215. doi:10.1016/s0145305x(02)00097-6

Shivers, R.P., Pagano, D.J., Kooistra, T., Richardson, C.E., Reddy, K.C., \& Whitney, J.K. 2010. Phosphorylation of the conserved transcription factor ATF-7 byPMK1p38MAPK regulates innate immunity in Caenorhabditis elegans. PLoS Genet. 6:e1000892

Sifri, C.D., Begun, J., \& Ausubel, F.M. 2005. The worm has turned microbial virulence modeled in Caenorhabditis elegans. Trends Microbiol. 13:119-127

Sprynski, N., Valade, E., \& Neulat-Ripoll, F. 2014. Galleria mellonella as an infection model for select agents. Methods Mol Biol. 1197:3-9

Strähle, U., Scholz, S., Geisler, R., Greiner, P., Hollert, H., \& Rastegar, S. 2012. Zebrafish embryos as analternative to animal experiments- a commentary on the definition of the on set of protected life stages in animal welfare regulations. Reprod Toxicol. 33:128-132

Sulston, J., \& Hodgkin, J. 1988. "Methods" in The Nematode Caenorhabditis elegans, ed.W.B.Wood (NewYork, NY:Cold Spring Harbor Laboratory Press):587-606

Sunyer, J.O., Boshra, H., \& Li, J. 2005. Evolution of anaphylatoxins, their diversity and novel roles ininnate immunity: insights from the study of fish complement. Vet Immunol Immunopathol. 108:7789

Tan, M.W., Mahajan-Miklos, S., \& Ausubel, F.M. 1999. Killing of Caenorhabditis elegans by Pseudomonas aeruginosa used to model mammalian bacterial pathogenesis. Proc Natl Acad Sci U.S.A. 96: 715-720

Van Leeuwen, L.M., van der Sar, A.M., \& Bitter, W. 2015. Animal models of tuberculosis: Zebrafish. Cold Spring Harb Perspect Med. 5:1-14

Whitten, M. M., Tew, I. F., Lee, B. L., \& Ratcliffe, N. A. 2004. A novel role for an insect apolipoprotein (apolipophorin III) in beta-1,3-glucan pattern recognition and cellular encapsulation reactions. $J$ Immunol, 172(4), 2177-2185. doi:10.4049/jimmunol.172.4.2177 